\title{
The effectiveness of GenoType MTBDRplus using in the diagnosis of tuberculosis in Zaporizhzhia region
}

\author{
R. M. Yasinskyi ${ }^{1}$, 0. M. Raznatovska ${ }^{1}$, 0. V. Konakova ${ }^{1}$, 0. M. Kamysnyi ${ }^{1}$, \\ N. A. Rokhmanova ${ }^{2}$, A. V. Klymenko ${ }^{2}$, Jean-Luc Berland ${ }^{3}$, Marie Gauhier ${ }^{3}$
}

${ }^{1}$ Zaporizhzhia State Medical University, Ukraine, ${ }^{2} \mathrm{Ml}$ “Zaporizhzhia Regional Antituberculous Clinical Dispensary”, Ukraine, ${ }^{3}$ Fondation Mérieux, Emerging Pathogens Laboratory, France

Key words: tuberculosis, diagnostic techniques and procedures, genotype, efficiency.

Pathologia 2017; 14 (2), 214-218

DOI:

10.14739/2310-1237.

2017.2.109670

E-mail:

phthisiologist@ gmail.com
The method GenoType MTBDRplus, v.2 allows to study clinical material from positive and negative smears, to examine patients with new and previously treated cases of tuberculosis pulmonary and extrapulmonary localization. But now there is a small amount of researches concerning the use of this method in the diagnosis of tuberculosis.

Aim. To evaluate the effectiveness of GenoType MTBDRplus, v. 2 method using in clinical material research due to the diagnosis of tuberculosis in the Zaporizhzhia region in comparison with standard methods of investigation.

Materials and methods. The analysis of 52 results of studies of clinical material using the GenoType MTBDRplus test system, v.2 from patients who were examined and treated in dispensaries of the Zaporizhzhia region in 2016 was carried out. There were $67.3 \%$ of men and $32.7 \%$ of women among the patients. The mean age of the patients was $46.0 \pm 1.9$ years. The study of the clinical material using the GenoType MTBDRplus test, v. 2 was performed according to the standard instructions.

Results. The results were positive in $12.5 \%$ of the cases when tested by GenoType MTBDRplus, v.2 $(p<0.05)$ among negative results of the microscopy of the clinical material. The proportion of coincidence between the cultural and molecular genetic methods was $90 \%$ for sputum and $100 \%$ for other clinical material. In the presence of multiresistance, both methods of investigation coincided in the number of detected cases (50\% for the GenoType MTBDRplus method, v.2 and $42.9 \%$ for the cultural method, respectively, $p<0.05$ ). In comparison with the results of the cultural method, the GenoType MTBDRplus test, v. 2 made it possible to establish resistance to rifampicin in $35.7 \%(p<0.05)$ of patients whose resistance was not determined. False-positive and false-negative results are due, perhaps, to the heterogeneity of strains of mycobacterium tuberculosis in clinical specimens, the absence of viable mycobacteria, the absence of phenotypic manifestations of mycobacterium tuberculosis genetic mutations, and errors in the investigations. The sensitivity of the GenoType MTBDRplus test, v. 2 is about $78 \%$, but the specificity reaches $97 \%$. At the same time, the sensitivity of the test for multidrug resistance determining reaches $100 \%$, the specificity is about $89 \%$. The greater positive predictive value for cases in which the DNA of mycobacteria is determined and the negative predictive value is for cases in which multidrug resistance is determined.

Conclusions. This indicates that the using of the GenoType MTBDRplus test, v.2, together with the cultural method of investigation, has a high diagnostic value, high sensitivity (100\%) and specificity ( $89 \%)$ for the definition of multiresistanc, and makes it possible to obtain a result in a short time compared to culture.

\section{Киючові слова:}

туберкульоз, Аіагностичні

технології, теcт genotype, ефективність.

Патологія. - 2017. T. 14, № 2(40). C. 214-218

\section{Ефективність застосування методу GenoType MTBDRplus у Аіагностиці туберкульозу в Запорізькій області}

\section{Р. М. Ясінський, О. М. Разнатовська, О. В. Конакова, О. М. Камишний, Н. А. Рохманова, А. В. Клименко, Жан-Люк Берланд, Марі Ґуйер}

Метод GenoType MTBDRplus 2 версії (GenoType MTBDRplus, v.2) дає можливість досліджувати клінічний матеріал із позитивних і негативних мазків, обстежувати хворих із новими та повторними випадками туберкульозу легень і позалегеневої локалізації. Але нині кількість досліджень щодо використання цього методу в діагностиці туберкульозу невелика.

Мета роботи - оцінити ефективність застосування методу дослідження клінічного матеріалу з використанням методу GenoType MTBDRplus, v.2 у діагностиці туберкульозу в Запорізькій області порівняно зі стандартними методами дослідження.

Матеріали та методи. Здійснили аналіз 52 результатів досліджень клінічного матеріалу за допомогою тест-системи GenoType MTBDRplus, v.2 від пацієнтів, які обстежувалися та лікувалися в диспансерах Запорізької області у 2016 році. Серед пацієнтів було 67,3 \% чоловіків і 32,7 \% жінок. Середній вік хворих становив 46,0 1 1,9 року. Дослідження клінічного матеріалу з використанням тесту GenoType MTBDRplus, v.2 здійснили за стандартом, відповідно до інструкції виробника.

Результати. При негативних результатах мікроскопії клінічного матеріалу у 12,5 \% випадках результати виявилися позитивними під час дослідження за допомогою методу GenoType MTBDRplus, v.2 ( $<<0,05)$. Частка збігів між культуральним і молекулярно-генетичним методами становила $90 \%$ для харкотиння та $100 \%$ для іншого клінічного матеріалу. За наявності мультирезистентності обидва методи дослідження майже збігалися за кількістю виявлених випадків (50,0 \% для методу GenoType MTBDRplus, v.2 та 42,9 \% для культурального методу відповідно, p > 0,05). Порівняно з результатами культурального методу, тест GenoType MTBDRplus, v.2 дав можливість встановити стійкість до рифампіцину у $35,7 \%$ $(p<0,05)$ пацієнтів, у яких не визначалася стійкість. Хибно-позитивні та хибно-негативні результати зумовлені, можливо, гетерогенністю штамів мікобактерій туберкульозу у клінічних зразках, відсутністю життєздатних мікобактерій, фенотипічних 
проявів генетичних мутацій мікобактерій туберкульозу, помилками під час дослідження тощо. Чутливість тесту GenoType MTBDRplus, v.2 становить майже $78 \%$, але специфрічність сягає $97 \%$. Натомість чутливість тесту щодо встановлення мультирезистентності сягає 100 \%, специфічність - майже 89 \%. Більша прогностична цінність позитивного результату для випадків, у яких визначаються ДНК МБТ, а прогностична цінність негативного результату - для випадків, у яких визначається мультирезистентність.

Висновки. Застосування тесту GenoType MTBDRplus, v.2. поряд із культуральним методом дослідження має високу діагностичну цінність, високу чутливість (100 \%) і специфічність (89 \%) щодо визначення мультирезистентності й дає змогу отримати результат у коротший термін порівняно з культуральним дослідженням.

\section{Эффективность использования метода GenoType MTBDRplus в диагностике туберкулёза в Запорожской области}

\section{Р. Н. Ясинский, Е. Н. Разнатовская, О. В. Конакова, А. М. Камышный, Н. А. Рохманова, А. В. Клименко, Жан-Кюк БерланА, Мари Гуйер}

Метод GenoType MTBDRplus, v.2 позволяет исследовать клинический материал с положительных и отрицательных мазков, обследовать больных с новыми и повторными случаями туберкулёза лёгких и внелёгочной локализации. Но в настоящее время количество исследований касательно использования данного метода в диагностике туберкулёза невелико.

Цель работы - оценить эффективность использования метода исследования клинического материала с применением метода GenoType MTBDRplus, v.2 в диагностике туберкулёза в Запорожской области в сравнении со стандартными методами исследования.

Материалы и методы. Проведён анализ 52 результатов исследований клинического материала с использованием тест-системы GenoType MTBDRplus, v.2 от пациентов, которые обследовались и лечились в диспансерах Запорожской области в 2016 году. Среди пациентов - 67,3 \% мужчин и 32,7 \% женщин. Средний возраст больных составлял 46,0 \pm 1,9 года. Исследование клинического материала с использованием теста GenoType MTBDRplus, v.2 проводили по стандарту, согласно инструкции.

Результаты. При отрицательных результатах микроскопии клинического материала в 12,5 \% случаев результаты оказались положительными при исследовании методом GenoType MTBDRplus, v.2 ( $<$ < 0,05). Доля совпадений между культуральным и молекулярно-генетическим методами составила 90 \% для мокроты и 100 \% для другого клинического материала. При наличии мультирезистентности оба метода исследования совпадали по количеству выявленных случаев (50 \% для метода GenoType MTBDRplus, v.2 и 42,9 \% для культурального метода соответственно, р < 0,05). В сравнении с результатами культурального метода, тест GenoType MTBDRplus, v.2 позволил установить устойчивость к рифампицину у 35,7 \% ( $<$ < 0,05) пациентов, у которых устойчивость не определялась. Ложно-положительные и ложно-отрицательные результаты обусловлены, возможно, гетерогенностью штаммов микобактерий туберкулёза в клинических образцах, отсутствием жизнеспособных микобактерий, фенотипических проявлений генетических мутаций микобактерий туберкулёза, ошибками при проведении исследования. Чувствительность теста GenoType MTBDRplus, v.2 cocтавляет около $78 \%$, но специфичность достигает $97 \%$. В то же время чувствительность теста по определению мультирезистентности достигает 100 \%, специфичность - около 89 \%. Большая прогностическая значимость положительного результата для случаев, в которых определяются ДНК микобактерий, а прогностическая значимость отрицательного результата - для случаев, в которых определяется мультирезистентность.

Выводы. Это свидетельствует о том, что использование теста GenoType MTBDRplus, v.2 вместе с культуральным методом исследования имеет высокую диагностическую ценность, высокую чувствительность (100 \%) и специфичность (89 \%) по определению мультирезистентности и даёт возможность получить результат в более короткий срок сравнительно с культуральным исследованием.

Molecular-genetic (MG) test system GenoType MTBDRplus, v.2 allows simultaneously identifying M. tuberculosis complex (MBT) in a clinical material (sputum, pleural fluid, bronchial aspirate, liquor from, etc.) and its resistance to rifampicin $(R)$, isoniazid $(H)[1,2,5]$. The complex polymerase chain reaction and followed hybridization on the strips and determination of mutations in different parts of the rpoB gene, causing the appearance of resistance to $R$, as well as in areas of gene katG and inhA, leading to the appearance of resistance to $\mathrm{H}$ are principles of the this method [2,5].

GenoType MTBDRplus, v. 2 method in contrast to v. 1 allow examination of clinical material not only from positive but also negative smears, in patients with newly diagnosed and recurrent cases of pulmonary tuberculosis and extrapulmonary localizations of tuberculosis [5].

According to the foreign author's researches, test system GenoType MTBDRplus, v.2 has high sensitivity, specificity, predictive value of positive and negative results allows to get results in the first 2 days of inspection, thereby increasing the efficiency of diagnosis chemo-resistant forms of tuberculosis $[3,6,7,9,10]$.

But these researches regarding method's sensitivity and specificity are different, there is a small amount of national investigations relating to the application GenoType MTBDRplus, v.2 method in the diagnosis of tuberculosis, this resulted in the necessity of our own research.

\section{The aim}

To evaluate the effectiveness of GenoType MTBDRplus, v. 2 method using in clinical material research due to the diagnosis of tuberculosis in the Zaporizhzhia region in comparison with standard methods of investigation.
Ключевые слова:

туберкулёз, Аиагностические технологии, тест genotype, эффективность.

Патология. - 2017. T. 14, № 2(40). C. 214-218 
Table 1. The results of investigation by cultural and molecular genetic methods compared with the results of microscopy of clinical material

\begin{tabular}{lllllll}
\hline \multirow{2}{*}{ The method } & \multirow{2}{*}{ Rezult } & \multicolumn{6}{l}{ The results of microscopy } \\
\cline { 3 - 7 } & & negative & 1-9 AFB & 1+ & 2+ & 3+ \\
\hline Cultural & Positive & $7^{*}$ & 1 & 3 & 2 & 5 \\
& Negative & 33 & 1 & 0 & 0 & 0 \\
\hline Geno Type MTBDRplus, v.2 & Positive & $5^{*}$ & 0 & 3 & 2 & 5 \\
& Negative & 35 & 2 & 0 & 0 & 0 \\
\hline In total, $\mathrm{n}=52$ & & 40 & 2 & 3 & 2 & 5 \\
\hline
\end{tabular}

*: significant difference between the results of the cultural, MG with smear microscopy results $(p<0.05)$.

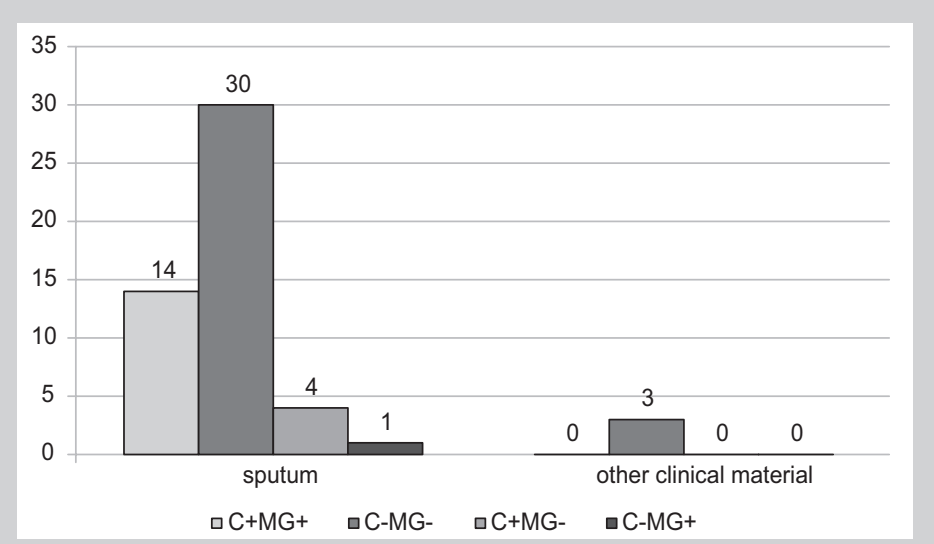

Fig. 1. The distribution of investigation results of clinical material by coincidence and differences between culture $(C)$ and MG methods.

\section{Materials and methods}

The analysis of 52 results of studies of clinical material using the GenoType MTBDRplus test system, v.2 from patients who were examined and treated in dispensaries of the Zaporizhzhia region in 2016 was carried out. There were $67.3 \%$ of men and $32.7 \%$ of women among the patients. The mean age of the patients was $46.0 \pm 1.9$ years. Comparison of the received results by using the GenoType MTBDRplus, v.2 test was performed with standard methods of MBT identification: Ziehl-Neelsen staining method, microbiological method using an automated system BACTEC MGIT 960, seeding on solid culture media Lowenstein-Jensen and Finn II (the data of BACTEC MGIT 960 results in all cases coincide with the results on solid nutrient media, so their total results regarded as a cultural investigation results) with a further determination of resistance to drugs [4]. Results of smear microscopy were evaluated as negative - in cases of absence of acid-fast bacilli (AFB), 1-9 AFB - the presence of the appropriate number of AFB in smear microscopy, " $1+$ " - in the presence of 10-99AFB in smear, "2+" - in the presence of 1-10 AFB in each vision's field of smear, " $3+$ " - in the presence of more than 10 AFB in each vision's field of smear [8].

In order to master the technique and for permission to perform this technique, physician-bacteriologist from Community institution "Zaporizhzhia regional clinical tuberculosis dispensary" was trained in the laboratory of new pathogens, Fondation Merieux (Lyon, France) from 12.01.2014 to 12.12.2014 in topic: "The identification of Mycobacterium tuberculosis complex (MTBC) and de- termine its resistance to rifampicin and/or isoniazid using GenoTypeMTBDRplus" and received the certificate.

The study of the clinical material using the GenoType MTBDRplus test, v. 2 was performed according to the standard instructions $[2,5]$.

Statistical analysis was performed by using "Statistica for Windows 6.0" (StatSoft Inc., № AXXR712D833214FAN5). Statistical significance of differences between groups in qualitative indicators was determined by the onetailed Fisher's exact criterion. For the levels of statistical significance values of the probability of the difference between the groups (p) levels of less than 0.05 were taken. We determined the sensitivity, specificity, predictive value of positive and negative results and their confidence intervals.

\section{Results and discussion}

The results of the Geno Type MTBDRplus, v.2 test data with culture investigation data of clinical material comparatively with the microscopy results were compared (Table 1).

We determined that the results of these tests coincided with the microscopy result " $3+$ ", "2+" and " $1+$ " in $100 \%$ of cases. If the result of microscopy was "1-9AFB" there was a coincidence of results with cultural test in $50 \%$ of cases. The results were positive in $17.5 \%$ of the cases when tested by cultural method and in $12.5 \%$ of the cases when tested by GenoType MTBDRplus, v.2 ( $<$ < 0.05) among negative results of the microscopy of the clinical material. Thus, in negative results of smear microscopy of clinical material GenoType MTBDRplus, v.2 test and the cultural method have significant diagnostic value.

We found that presence of MBT DNA in clinical material was not detected by cultural test in 1 case, MBT were diagnosed only by using test system GenoType MTBDRplus, v. 2 when comparing the results of diagnostic methods. In 4 cases MBT were found only by cultural method, and MG test system Geno Type MTBDRplus, v.2 showed negative results (Fig. 1).

The proportion of coincidence between the culture and molecular genetic methods was $90 \%$ for sputum and $100 \%$ for other clinical material.

False-positive and false-negative results are due, perhaps, to the heterogeneity of strains of mycobacterium tuberculosis in clinical specimens, the absence of viable mycobacteria, the absence of phenotypic manifestations of mycobacterium tuberculosis genetic mutations, and errors in the investigations.

When analyzing coincidence of positive results between test GenoType MTBDRplus, v. 2 and cultural method we found that resistance to anti-tuberculosis drugs $(H / R)$ by the cultural method was determined in $64 \%$ of patients (Table 2). Mutations in the genotype of MBT that are responsible for resistance to $H / R$ were determined in 93 $\%$ of patients by the GenoType MTBDRplus, v. 2 method.

In the presence of drug resistance HR (multiresistance), both methods of investigation coincided in the number of detected cases (50\% for the GenoType MTBDRplus method, v.2 and $42.9 \%$ for the cultural method, respectively, $p>0.05$ ). But the use of MG test allows you to receive the result within two days, which proves its diagnostic value. 
In comparison with the results of the cultural method, the GenoType MTBDRplus test, v. 2 made it possible to establish resistance to rifampicin in $35.7 \%(p<0.05)$ of patients whose resistance was not determined.

That is, in a positive result of GenoType MTBDRplus, v. 2 test its informativeness in determine resistance to drugs exceeded cultural method by almost $30 \%$. The difference between the results of MG and cultural methods, perhaps, due to the fact that not always the mutations that cause the occurrence of resistance to drugs appear phenotypically, as well as heterogeneity of strains of the pathogen.

Sensitivity, specificity and predictive value of Geno Type MTBDRplus, v. 2 method was established compared to cultural results (Table 3).

According to the preliminary results of the investigation we found, that the sensitivity of the GenoType MTBDRplus test, v. 2 is about $78 \%$, but the specificity reaches $97 \%$. At the same time, the sensitivity of the test for multidrug resistance determining reaches $100 \%$, the specificity is about $89 \%$. The greater positive predictive value for cases in which the DNA of MBT is determined and the negative predictive value is for cases in which multidrug resistance is determined.

\section{Conclusions}

1. According to the preliminary results of the investigation we found, that the use of GenoType MTBDRplus, v. 2 test system allows determining additional $12.5 \%$ of patients with bacterial excretion among patients with negative smears, $p<0.05$. The proportion of coincidence between the cultural and molecular genetic methods is 90 $\%$ for sputum and $100 \%$ for other clinical material.

2. Test system GenoType MTBDRplus, v.2 allows establishing resistance to rifampicin in $35.7 \%(p<0.05)$ patients, in comparison with the results of the cultural method. The proportion of multi-resistance detection is almost the same, but the diagnostic value of molecular genetic test is explained by much greater speed of results receiving (within two days versus to $2-3$ weeks by use an automated system BACTEC MGIT 960 and 2-3 months - while use solid cultural media).

3. The specificity of positive result of GenoType MTBDRplus test, v. 2 is $97 \%$, the sensitivity of the test for multidrug resistance determining reaches $100 \%$. The greater positive predictive value has MG method $(93.3 \%)$, and the negative predictive value - multidrug resistance determining (100\%).

Perspectives of further researches. Further investigation of clinical material from patients with pulmonary tuberculosis I and II categories of dispensary observation in Zaporizhzhia region by using a Geno Type MTBDRplus, v.2 test system according to the project Fondation Merieux (France and ZSMU, Ukraine). It is planned to add this method with determination of resistance to second-line anti-tuberculosis drugs 2, identification of nontuberculous MBT.

Funding: material and technical support of research has been granted by Fondation Mérieux (France) on the basis of a memorandum between Zaporizhzhia State Medical University (Ukraine) and Fondation Mérieux (France), 2015.
Table 2. The distribution of investigation results of resistance to drugs by coincidence and differences between cultural and MG methods

\begin{tabular}{|c|c|c|c|c|}
\hline \multicolumn{2}{|c|}{$\begin{array}{l}\text { Positive results of cultural methods, } \\
N=14\end{array}$} & \multirow[t]{2}{*}{ resistance } & \multicolumn{2}{|c|}{$\begin{array}{l}\text { Positive results of Geno Type } \\
\text { MTBDRplus, v. } 2 \text { method, } \\
N=14\end{array}$} \\
\hline abs. & $\%$ & & abs. & $\%$ \\
\hline 5 & 35.7 & H “-”, R “-” & 1 & 7.2 \\
\hline 0 & 0 & H “-”, R “+” & 5 & $35.7^{*}$ \\
\hline 3 & 21.4 & H “+”, R “-” & 1 & 7.1 \\
\hline 6 & 42.9 & H “+”, R “+” & 7 & 50.0 \\
\hline
\end{tabular}

*: significant difference between the results of cultural and MG methods $(p<0.05)$.

Table 3. Sensitivity, specificity and predictive value of Geno Type MTBDRplus, v. 2 method

\begin{tabular}{lll}
\hline Parameters & Positive test & Resistance to HR \\
\hline Sensitivity (confidence interval) & $77.8 \%$ & $100.0 \%$ \\
& $(59.6-83.0 \%)$ & $(61.6-100.0 \%)$ \\
Specificity (confidence interval) & $97.1 \%$ & $88.9 \%$ \\
& $(87.4-99.8 \%)$ & $(63.3-88.9 \%)$ \\
Predictive value of positive result & $93.3 \%$ & $85.7 \%$ \\
(confidence interval) & $(71.5-99.6 \%)$ & $(52.8-85.7 \%)$ \\
Predictive value of negative result & $89.2 \%$ & $100.0 \%$ \\
(confidence interval) & $(80.3-91.7 \%)$ & $(71.2-100.0 \%)$ \\
\hline
\end{tabular}

References

[1] Pustovyi, Yu. H., Baranova, V. V., Hritsova, N. A., \& Dolynska, M. H. (2013). Vykorystannia molekuliarno-henetychnoho metodu GENOTYPE® MTBDRPLUS dlia rannoi diahnostyky multyrezystentnoho tuberkulozu [Using of molecular genetic methods GENOTYPE® MTBDRPLUS for early diagnosis of MDR TB]. Ukrainskyi pulmonolohichnyi zhurnal, 3, 130. [in Ukrainian].

[2] Barbova, A. I., Zhurylo, O. A. Zherebko, N. M. \& Chaika, A. O. (2014). Poriadok vykorystannia molekuliarno-henetychnykh metodiv u laboratoriiakh z diahnostyky tuberkulozu $v$ Ukraini [The procedure of using molecular genetic techniques in the laboratory diagnosis of tuberculosis in Ukraine]. Kyiv. [in Ukrainian].

[3] Nosova, E. Y., Krasnova, M. A., Galkina, K. Y., Makarova, M. V., Litvinov, V. I., Moroz, A. M. (2013). Sravnitel'naya ocenka e'ffektivnosti molekulyarnykh test-sistem «TB-Biochip», «Xpert MTB/Rif» i «GenoType MTBDRplus» dlya bystrogo opredeleniya mutacij, otvetstvennykh za lekarstvennuyu ustojchivost' Mycobacterium tuberculosis complex (v respiratornom materiale pacientov Moskovskogo regiona) [Comparative analysis of TB-Biochip, Xpert MTB/RIF, and GenoType MTBDRplus test systems for rapid determination of mutations responsible for drug resistance of M. tuberculosis complex (in sputum from patients in Moscow region)]. Molekulyarnaya biologiya, 47(2), 236-241. [in Russian].

[4] Zhurylo, O. A., Barbova, A. I., Hlushkevych, T. H., \& Tretiakova, L. V. (2012). Standarty bakteriolohichnoi diahnostyky tuberkulozu v laboratoriiakh protytuberkuloznykh zakladiv Ukrainy [The standards of bacteriological diagnosis of tuberculosis in the laboratory TB facilities in Ukraine: study guide]. Kyiv. [in Ukrainian].

[5] Alenova, A. X., Abyldaev, T. Sh., Zhumadylov, Zh. Sh., Berykova, E. A., Terlykbaeva, A. M., Berykxanova, K. E., et al. (2013). Struktura $i$ algoritmy novejshikh molekulyarno-geneticheskikh tekhnologij e'kspress diagnostiki tuberkuleza i lekarstvennoj ustojchivosti v Respublike Kazahstan [Structure and algorithms of the newest molecular genetic technologies for the rapid diagnosis of tuberculosis and drug resistance in the Republic of Kazakhstan]. Almaty. [in Russian].

[6] Seifert, M., Ajbani, K., Georghiou, S. B., Catanzaro, D., Rodrigues, C., Crudu, V., et al. (2016). A performance evaluation of MTBDRplus version 2 for the diagnosis of multidrug-resistant tuberculosis. The international journal of tuberculosis and lung disease, 20(5), 631-637. doi: 10.5588/ ijtld.15.0788.

[7] Lyu, J., Kim, M. N., Song, J. W., Choi, C. M., Oh, Y. M., Lee, S. D., et al. (2013). GenoType® MTBDRplus assay detection of drug-resistant tuberculosis in routine practice in Korea. The international journal of tuberculosis and lung disease, 17(1), 120-124. doi: 10.5588/ijtld.12.0197.

[8] European centre for disease prevention and control (2016) Handbook on TB laboratory diagnostic methods for the European Union. Stockholm.

[9] Simons, S. O., Van der Laan, T., De Zwaan, R., Kamst, M., Van Ingen, J. Dekhuijzen, P. N. R., et al. (2015). Molecular drug susceptibility testing in the Netherlands: performance of the MTBDRplus and MTBDRsI assays. The international journal of tuberculosis and lung disease, 19(7), 828-833. doi: 10.5588/ijld.15.0043. 
[10] Singh, L. S., Mazumder, P. B., \& Sharma, G. D. (2014). Analysis of mutational pattern in multidrug resistant tuberculosis (MDR TB) in a geographically isolated northeastern region of India. IOSR Journal of Pharmacy and Biological Sciences, 9(1), 04-10. doi: 10.9790/3008-09130410.

\section{Information about authors:}

Yasinskyi R. N., MD, PhD, Assistant of the Department of Phthisiology and Pulmonology Zaporizhzhia State Medical University, Ukraine.

Raznatovska O. M., MD, PhD, DSc, Associate Professor, Professor of the Department of Phthisiology and Pulmonology Zaporizhzhia State Medical University, Ukraine.

Konakova O. V., MD, PhD, Assosiate Professor of the Department of Pediatric Infectious Diseases Zaporizhzhia State Medical University, Ukraine.

Kamyshnyi O. M., MD, PhD, DSc, Professor, Head

of the Department of Microbiology, Virology and Immunology,

Zaporizhzhia State Medical University, Ukraine.

Rokhmanova N. A., doctor-bacteriologist of the bacteriological department of the clinical diagnostic laboratory of the municipal institution «Zaporizhzhia Regional Antituberculous Clinical Dispensary", Ukraine.

Klymenko A. V., laboratory assistant of the bacteriological department of the clinical diagnostic laboratory of the municipal institution "Zaporizhzhia Regional Antituberculous Clinical Dispensary", Ukraine.

Jean-Luc Berland, Researcher, Fondation Mérieux, Emerging Pathogens Laboratory (EPL), France.

Marie Gauhier, Researcher, Fondation Mérieux, Emerging Pathogens Laboratory (EPL), France.

\section{Відомості про авторів:}

Ясінський Р. М., канА. меА. наук, асистент каф. фтизіатрії і пульмонології, Запорізький Аержавний медичний університет, Україна.

Разнатовська О. М., А-р меА. наук, Аоцент, професор каф. фтизіатрії і пульмонології, Запорізький державний меАичний університет, Україна.

Конакова О. В., канд. меА. наук, Аоцент каф. Аитячих інфекційних хвороб, Запорізький Аержавний медичний університет, Україна. Камишний О. М., А-р меА. наук, професор,

зав. каф. мікробіології, вірусології та імунології, Запорізький Аержавний медичний університет, Україна.

Рохманова Н. А., лікар-бактеріолог бактеріологічного віАділу кмініко-Аіагностичної мабораторії КУ «Запорізький обласний протитуберкульозний клінічний Аиспансер", Україна.

Клименко А. В., ^аборант-бактеріолог бактеріологічного відАілу клініко-діагностичної лабораторії КУ «Запорізький обласний протитуберкульозний кмінічний Аиспансер", Україна.

Жан-^юк БерланА, АосліАник, ФонА Мерьє, Аабораторія патогенних збудників, Франція.

Марі Ґуйєр, Аослідник, ФонА Мерьє, Аабораторія патогенних збудників, Франція.

\section{Сведения об авторах:}

Ясинский Р. Н., канА. меА. наук, ассистент каф. фтизиатрии и пульмонологии, Запорожский государственный меАицинский университет, Украина.

Разнатовская Е. Н., А-р меА. наук, Аоцент, профессор

каф. фтизиатрии и пульмонологии, Запорожский

государственный меАицинский университет, Украина.

Конакова О. В., канА. меА. наук, ассистент каф. Аетских инфекционных болезней, Запорожский государственный медицинский университет, Украина.

Камышный А. М., А-р меА. наук, профессор, зав. каф. микро-

биологии, вирусологии и иммунологии, Запорожский государственный меАицинский университет, Украина. Рохманова Н. А., врач-бактериолог бактериологического отдела клинико-диагностической маборатории КУ «Запорожский областной противотуберкулезный кминический Аиспансер", Украина.

Клименко А. В., ^аборант-бактериолог бактериологического отАела клинико-диагностической маборатории КУ «Запорожский областной противотуберкулезный клинический Аиспансер", Украина.
Жан-^юк БерланА, исследователь, ФонА Мерьё, ^аборатория патогенных возбудителей, Франция.

Мари Гуйер, исследователь, ФонА Мерьё, ^аборатория патогенных возбудителей, Франция.

Конфмікт інтересів: віАсутній.

Conflicts of Interest: authors have no conflict of interest to declare.

Надійшло до редакції / Received: 31.03.2017

Після Аоопрацювання / Revised: 14.04.2017

Прийнято Ао Аруку / Accepted: 19.04.2017 